\title{
New species records of systellognathan stoneflies (Plecoptera: Systellognatha) for the fauna of the Korean Peninsula*
}

\author{
D. MurÁnYi ${ }^{1}$, J.M. HwANG ${ }^{2}$, M.J. JEON ${ }^{3} \&$ H.Y. SEO ${ }^{3}$
}

\begin{abstract}
${ }^{1}$ Dávid Murányi, Department of Civil and Environmental Engineering, Ehime University, Bunkyo-cho 3, Matsuyama, 790-8577 Japan, and Department of Zoology, Hungarian Natural History Museum, H-1088 Budapest, Baross u. 13, Hungary.E-mail: muranyi@ cee.ehime-u.ac.jp, muranyi@zool.nhmus.hu ${ }^{2} J e o n g$ Mi Hwang, Korean Entomological Institute, Korea University, Anam-dong, Seongbuk-gu, Seoul 136-701, Republic of Korea. E-mail: msmay74@korea.ac.kr

${ }^{3}$ Mi Jeong Jeon, Hong Yul Seo, Animal Research Division, National Institute of Biological Resources, Gyoungseo-dong, Seo-gu, Incheon 404-708, Republic of Korea. E-mails: jeonmj@korea.kr, syseo@korea.kr
\end{abstract}

\begin{abstract}
Three species of stoneflies are reported for the first time from the Korean Peninsula: Pictetiella asiatica Zwick \& Levanidova, 1971, Xanthoneuria unimaculata (Zhiltzova, 1979) and a new species of the genus Sweltsa Ricker, 1943. The widespread temperate Asian species, P. asiatica, represents the first record of the Transpacific genus Pictetiella Illies, 1966 from Korea. Xanthoneuria unimaculata confirms the presence of Xanthoneuria Uchida, 2011 in Korea. This genus was hitherto known only from Japan and the Russian Far East with a dubious record from Korea. The female of Sweltsa sp. is formally described but not named because male remained unknown. All the specimens were collected in North Korea by colleagues from the Hungarian Natural History Museum during the 1970's and 1980's. New Korean records of further ten species are also enumerated, with notes about some doubtful records. Distribution area of the genera Pictetiella and Xanthoneuria are detailed and depicted on maps.
\end{abstract}

Keywords. Aquatic insects, Pictetiella asiatica, Xanthoneuria unimaculata, Sweltsa sp., distribution, North Korea

\section{INTRODUCTION}

$\mathrm{D}$ espite that the first Korean stonefly was reported relatively early from the Yalu River (Banks 1920), the Korean Plecoptera fauna was essentially unknown until the seventies (Zwick 1973a, 1973b). The fauna remained poorly known until the 1990s when intensive research was launched (Kim et al. 1998). Today, the Korean stoneflies fauna is relatively well known, with 77 species reported however, nearly one third was published only during the last five years (Murányi \& Park 2011, Murányi et al. 2014, 2015, Stark 2010, Zwick 2010, Zwick \& Baumann 2011). Unfortunately, our knowledge on the two Korean countries is very unbalanced, as 61 of the 77 species are known from South Korea (Murányi \& Park 2011, Zwick \& Baumann 2011) while only 34 species is registered for North Korea (Ham 2008, Murányi et al. 2014, 2015).
Between 1970 and 1994, colleagues from the Hungarian Natural History Museum had the opportunity to take 16 collecting expeditions to North Korea (Mahunka \& Steinmann 1971, Mészáros \& Zombori 1995). These efforts yielded some Plecoptera, but this material was only partially studied (Murányi et al. 2014, 2015, Stark \& Sivec 2008b, Zwick 1973b). Here, we report on the Systellognathan genera Xanthoneuria Uchida, 2011 (in: Uchida et al. 2011), Pictetiella Illies, 1966 and Sweltsa Ricker, 1943 from the collection, including three species ( $P$. asiatica Zwick \& Levanidova, 1971; X. unimaculata (Zhiltzova, 1979) and a new species of the genus Sweltsa which represent new records for the Korean peninsula. Consequently, the number of stoneflies recorded from Korea is raised to 80 . However, occurrence of some species reported from North Korea are questionable. We also discuss these doubts, and present distribution maps of the genera Pictetiella and Xanthoneuria.

urn: 1sid:zoobank.org:pub:88609CC7-DD52-4467-A257-864CEF67AE59

HU ISSN 2063-1588 (online), HU ISSN 0237-5419 (print) http://dx.doi.org/10.18348/opzool.2016.2.111

*Zoological Collectings by the Hungarian Natural History Museum in Korea No. 210 


\section{MATERIAL AND METHODS}

Specimens were stored dry in the Collection of Smaller Insect Orders, Department of Zoology, Hungarian Natural History Museum, Budapest, Hungary (HNHM). They were relaxed and transferred to vials with $70 \%$ ethanol, their terminalia were cleared in $\mathrm{KOH}$. The material studied are deposited in the HNHM and in the National Institute of Biological Resources, Incheon, Republic of Korea (NIBR).

Epiproct and aedeagus were everted using the cold maceration technique of Zwick (1983). Illustrations were made with the aid of a drawing tube applied on a Nikon SMZ800 microscope. Terminology mainly follows Li et al. (2014), Teslenko \& Minakawa (1999), Uchida et al. (2011) and Zwick \& Weinzierl (1995).

Distributional data were compiled from literature data from various sources referenced in Plecoptera Species File (PSF) (DeWalt et al. 2015), but mainly from Teslenko \& Zhiltzova (2009) and Uchida (1990).

\section{RESULTS AND DISCUSSION}

\section{Perlidae}

\section{Xanthoneuria Uchida, 2011}

Xanthoneuria Uchida, 2011: Uchida et al. 2011: 65. (original description on the basis of male, female and larva, by four species included); DeWalt et al. 2015, (catalog).

Japoneuria Uchida, 1990: Uchida 1990: 123. (manuscript name).

Type species. Acroneuria fulva Klapálek, 1907 , by original designation. Further species included: Xanthoneuria bolivari (Klapálek, 1907); X. jouklii (Klapálek, 1907), X. unimaculata (Zhiltzova, 1981).

This recently described genus contains three species restricted to Japan, and a coastal mainland species known from the Russian Far East and North Korea (Fig. 11).

\section{Xanthoneuria unimaculata (Zhiltzova, 1981)}

(Figures 1-3)

Xanthoneuria unimaculata (Zhitzova, 1981): Uchida et al. 2011: 65. (comb. n.), DeWalt et al. 2015, (catalog).

Acroneuria unimaculata Zhiltzova, 1981: 5. (original description of male and female); Zhiltzova 1995: 14. (type catalogue of RAS specimens).

Acroneuria unimaculata Zhiltzova, 1979: Teslenko \& Zhiltzova 2009: 54. (monograph, with mistaken date).

Japoneuria unimaculata (Zhiltzova, 1981): Uchida 1990: 123. (manuscript name, comb. n.).

Type locality. Russia, Primorsky Krai, Komissarovka River, Barabash Settlement, Pogranichny Raion (holotype), "Kedrovaya Pad" Reserve (paratypes).

Material examined. North Korea. North Pyongan Province, Hyangsan-gun, Myohyang Mts, at light on the balcony and garden of Hotel Myohyang-san (locality No. 793), $150 \mathrm{~m}, \mathrm{~N} 40^{\circ} 00^{\prime}$ E126ํ15', 14.vii.1982, leg. László Forró, László Ronkay: 19; North Pyongan province, Hyangsangun, Myohyang Mts, singled in the valley below Hwajangam (locality No. 816), $300 \mathrm{~m}, \mathrm{~N} 40^{\circ} 00^{\prime}$ E126¹6', 17.vii.1982, leg. László Forró, László Ronkay: 1; ; North Pyongan Province, Hyangsangun, Myohyang Mts, at light on the balcony and garden of Hotel Myohyang-san (locality No. 829), 150 m, N4000' E126²15', 18.vii.1982, leg. László Forró, László Ronkay: $1 \delta^{\lambda}$.

Distribution and ecology. The species was described from the southern part of Russian Far East, and hitherto had no concrete data from elsewhere (Teslenko 2012). Uchida et al. (2011) reported it also from Korea, but without any detailed locality. Probably, they referred to the data of X. joukli from the Baekdu Mts (Kim et al. 1993), see below. The present specimens are all from the lower regions of Myohyang Mountains, forming the western chain of the Changbai (Baekdu) range that separates the Korean Peninsula from the Asian continent (Figs. 11, 13). At locality No. 816 it was the only stonefly caught, while at the light trap (No. 793 and 829) it was caught together with other perlids: Paragnetina flavotincta (McLachlan, 1872), Neoperla coreensis Ra, Kim, Kang \& Ham, 1994 and a paratype of $N$. goguryeo Murányi \& Li, 2015 (in Murányi et al, 2015). 
Remarks. The Korean specimens agree well with the original description (Figs. 1-3). The aedeagus bears no spines or hairs, contrary to the Japanese species (Uchida et al. 2011). It was not possible to evert because of the poor condition of the specimen, so lobes and shape remained unknown. Unfortunately, the two females had no eggs, so details of the egg also remained unknown.

\section{Perlodidae}

\section{Pictetiella Illies, 1966}

Pictetiella Illies, 1966: 374. (replacement name for Pictetia Banks, 1948 non Pictetia Uhlig, 1882 (Mollusca) nec. Pictetia Brongniart, 1885 (Insecta); by monotypy, catalog); Zwick 1973: 237. (catalog), Stewart \& Stark 2002: 434. (monograph); DeWalt et al. 2015, (catalog).

Pictetia Banks, 1948: 281. (original description on the basis of imago somatic features, by monotypy).

Isogenus (Pictetia) Banks, 1948: Ricker 1952: 120. (comb. $\mathrm{n}$., description of male and larva, complementary description of female).

Type species. Perla expansa Banks, 1920 inherited from the replaced name by monotypy. Further species included: Pictetiella asiatica Zwick \& Levanidova, 1971 (in Zwick et al. 1971), P. lechleitneri Stark \& Kondratieff, 2004, P. zwicki Zhiltzova, 1976 (in Levanidova \& Zhiltzova 1976).

This Transpacific genus contains two western Nearctic and two East Palaearctic species. Despite its wide distribution in the Asian part of Russia, the genus is hitherto unknown from China and Japan (Fig. 12).

\section{Pictetiella asiatica Zwick \& Levanidova, 1971}

$$
\text { (Figs. 4-8) }
$$

Pictetiella asiatica Zwick \& Levanidova, 1971: Zwick et al. 1971: 853. (original description of male, female and larva), Zwick 1973: 238. (catalog), Zhiltzova \& Zapekina-Dulkeit 1986: 183. (complementary description of the imago), Zhiltzova 1995: 7. (type catalogue of RAS specimens), Teslenko \& Zhiltzova 2009: 32, 266. (monograph); Judson \& Nelson, 2012: 44 (complementary description of male and female).
Type locality. Russia, Kamchatka Peninsula, Kirpichnaya River (Kamchatka River Basin), Mil'kovo settlement.

Material examined. North Korea. Ryanggang province, Samjiyŏn-gun, Baekdu Mts, singled in mixed larch-birch forest along a road (locality No. 197), 1600 m, N41 ${ }^{\circ} 50^{\prime}$ E128¹5', 25.viii.1971, leg. Sándor Horvatovich, Jenő Papp: 10̂̃; Ryanggang province, Samjiyŏn-gun, Baekdu Mts, at light by a small lake behind Hotel Samjiyŏn (locality No. 373), $1700 \mathrm{~m}, \mathrm{~N} 41^{\circ} 50^{\prime} \mathrm{E} 128^{\circ} 15^{\prime}$, 18.vii.1977, leg. Olivér György Dely, Ágnes Dely-Draskovits: 10 .

Distribution and ecology. The species has wide distribution in Russia, from the Altai ranges to Kamchatka, recently was also reported from northern Mongolia. The present specimens are from the Baekdu Mountains, the central and highest chains of the Changbai (Baekdu) ranges. These records constitutes the southernmost distribution of the species (Figs. 12-13). At locality No. 373 it was the only stonefly caught at the light trap, while at locality No. 197 it was singled together with an unassociable Amphinemura Ris, 1902 female and with a male of Kamimuria zwicki Stark \& Sivec, 2008a. The latter species is new for the fauna of North Korea and slightly extends its known range, as hitherto it was only known from South Korea. Perlidae gen. spec. in Zwick (1973a) probably also refers to this species.

Remarks. The Korean specimens mostly agree with the original description, and Dr. Valentina A. Teslenko kindly verified their probable conspecifity with the Russian specimens. However, some slight differences are worth to note (Figs. 4-8): finger-like projection of the epiproct tip is longer, and the epiproct tip possesses stronger dorsal sclerotization on the Korean specimens, resembling more to the epiproct tip of the Nearctic $P$. expansa than those of $P$. asiatica.

\section{Chloroperlidae}

\section{Sweltsa Ricker, 1943}

Alloperla (Sweltsa) Ricker, 1943: 135. (original description on the basis of male, female and larva, by twelve species included). 
Sweltsa Ricker, 1943: Illies 1966: 450. (stat. n. as a genus, catalog), Zwick 1973: 297. (catalog), Surdick 1985: 23. (revision), Stewart \& Stark 2002: 280. (monograph), DeWalt et al. 2015, (catalog).

Type species. Alloperla oregonensis Frison, 1935 , by original designation. Further species included: 48 valid species (according to PSF), among them the followings are from Asia: Sweltsa abdominalis (Okamoto, 1912); S. assam Zwick, 1971; S. baiyunshana Li, Yang \& Yao, 2014; S. colorata Zhiltzova \& Levanidova, 1978; S. illiesi Zhiltzova \& Levanidova, 1978; S. insularis Zhiltzova, 1978 (in Zhiltzova \& Levanidova, 1978); S. kibunensis (Kawai, 1967); S. lepnevae Zhiltzova, 1977; S. longistyla (Wu, 1938); S. nikkoensis (Okamoto, 1912); S. recurvata (Wu, 1938); S. shibakawae (Okamoto, 1912); S. wui Stark \& Sivec, 2009; S. yunnan Tierno de Figueroa \& Fochetti, 2002; S. zhiltzovae Zwick, 2010.

This Transpacific genus contains 33 western Nearctic, 12 East Palaearctic and 3 Oriental species. Among the East Palaearctic species, four poorly known species are restricted to Japan, a further one is known from the Pacific isles Sachalin, Kunashir and Shikotan. Three species are known from Central China, while the remaining four known from the coastal regions: $S$. zhiltzovae is known only from South Korea (Zwick, 2010), S. colorata and S. lepnevae were reported from the Russian Primorsky Krai and South Korea (Kim et al. 1998, Teslenko \& Zhiltzova 2009, Zwick 2010), while S. illiesi has a wider distribution ranging from the Amurskaya Oblast of Russia through the Primorsky Krai and North Korea to South Korea (Ham 2008, Teslenko \& Zhiltzova 2009). Sweltsa colorata, S. lepnevae and a further new species are reported from North Korea herein.

\section{Sweltsa colorata Zhiltzova \& Levanidova, 1978}

Sweltsa colorata Zhiltzova \& Levanidova, 1978: 20. (original description of male, female and larva), Zhiltzova 1995: 15. (type catalogue of RAS specimens), Teslenko \& Zhiltzova 2009: 83, 307. (monograph).

Sweltsa nikkoensis (Okamoto, 1912): Kim et al. 1998: 422. (synonymy of $S$. colorata, first Korean records; synonymy was disregarded by Teslenko \& Zhiltzova 2009 and Zwick 2010), Ham 2008: 186. (complementary description of male and female).

Type locality. Russia, Primorsky Krai, Kedrovaya River, "Kedrovaya Pad" Reserve.

Material examined. North Korea. Pyongyang Capital City, Mt. Taesong, at light (locality No. 923), N3904' E12549', 17.v.1985, leg. András Vojnits, Lajos Zombori: 19; North Pyongan Province, Hyangsan-gun, Myohyang Mts, swept at Hyangsan Stream (locality No. 930), $500 \mathrm{~m}$, N4000' E126¹5', 21.v.1985, leg. András Vojnits, Lajos Zombori: 1q; North Pyongan province, Hyangsan-gun, Myohyang Mts, at light on the hotel balcony (locality No. 933), N40 00 ' E126²15', 21.v.1985, leg. András Vojnits, Lajos Zombori: $10{ }^{\lambda} 1$; ; North Pyongan province, Hyangsan-gun, Myohyang Mts, singled at Hyangsan Stream (locality No. 935), N40 $00^{\prime}$ E $126^{\circ} 15^{\prime}, 22$. v.1985, leg. András Vojnits, Lajos Zombori: 1q; Kangwon Province, Kosŏng-gun, Kumgang Mts, swept along footpath from Kumgang-mun Gate to Kuryong Falls (locality No. 951), N38 ${ }^{\circ} 40^{\prime}$ E128 10', 27.v.1985, leg. András Vojnits, Lajos Zombori: 2 ; ; Kangwon province, Kosŏng-gun, Kumgang Mts, Oe-Kumgang rest house, swept in mixed forest (locality No. 952), N38 $8^{\circ} 40^{\prime}$ E $128^{\circ} 15^{\prime}$, 27.v.1985, leg. András Vojnits, Lajos Zombori: $1 \delta$ 1우 Kangwon Province, Kosŏng-gun, Kumgang Mts, swept in forest at Kwinyon-am Rock (locality No. 956), N38 40' E128¹5', 28.v.1985, leg. András Vojnits, Lajos Zombori: $1{ }^{\widehat{\gamma}}$.

Distribution and ecology. The species was known from the Russian Primorie and numerous places in South Korea, but not yet reported from North Korea (Fig. 13). On Mt. Taesong it was collected together with Perlomyia martynovi (Zhiltzova, 1975) and Amphinemura coreana Zwick, 1973b. In the Myohyang Mts. it was the only stonefly collected at localities No. 933 and 935, while at Hyangsan Stream (locality No. 930) it was found together with Perlomyia secunda (Zapekina-Dulkeit, 1955) and Sweltsa lepnevae. In the Kumgang Mts. it was collected together with Perlomiya $s p$. at the Kuryong Falls (locality No. 951), with A. coreana at Oe-Kumgang (locality No. 952), while with a wider set of sepcies in the forest at Kwinyon-am Rock (locality No. 

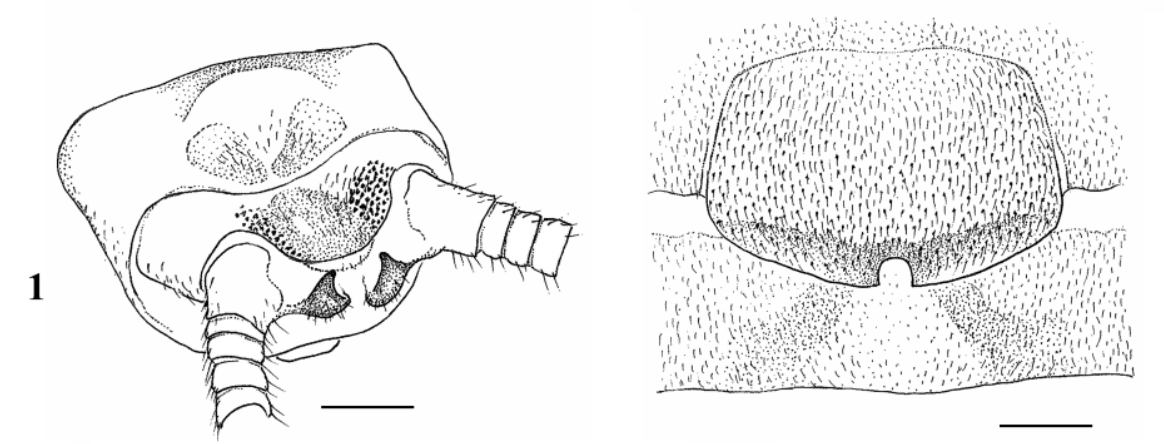

3
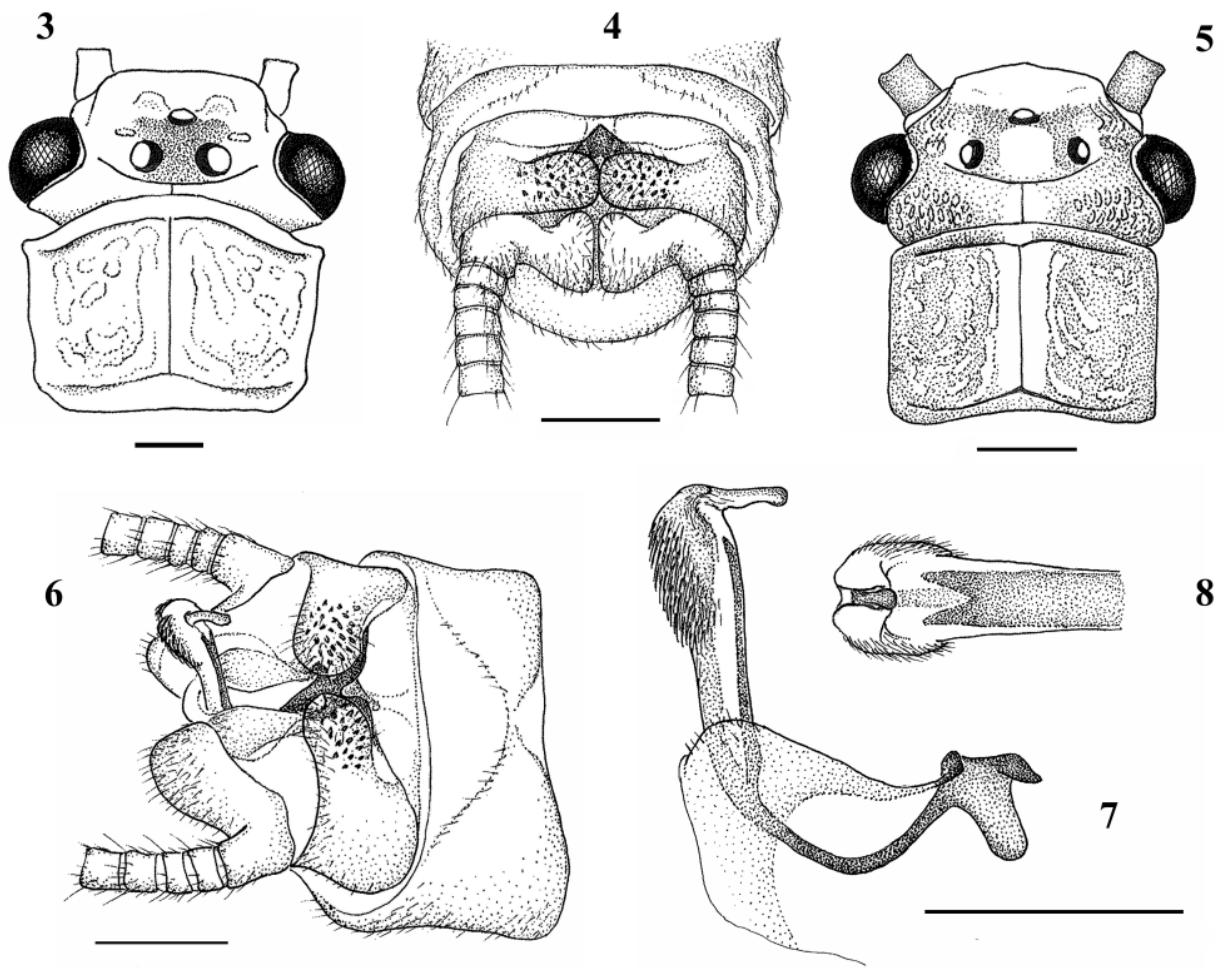

Figures 1-8. Xanthoneuria unimaculata (Zhiltzova, 1981) from Myohyang Mts, North Korea (1-3) and Pictetiella asiatica Zwick \& Levanidova, 1971 from Baekdu Mts, North Korea (4-8). 1 = male terminalia, dorso-caudal view; 2 = female sterna $8-9$, ventral view; $3=$ male head and pronotum, dorsal view; $4=$ male terminalia before $\mathrm{KOH}$ threatment, dorsal view; 5 male head and pronotum, dorsal view; $6=$ male terminalia after $\mathrm{KOH}$ threatment, dorso-lateral view; $7=$ everted male epiproct, lateral view; $8=$ male epiproct tip, dorsal view. Scales $1 \mathrm{~mm}$.

956): Perlomyia kiritshenkoi Zhiltzova, 1974, P. mahunkai (Zwick, 1973b), P. smithae Nelson \& Hanson, 1973, Perlomyia sp. an unassociable Nemoura Latreille, 1796 female and three females of the same Chloroperlidae species that was published as Triznaka $s p$. by Zwick (1973b). Records of the above Perlomyia Banks, 1906 species were already enumerated by Murányi et al. (2014).

\section{Sweltsa lepnevae Zhiltzova, 1977}

\section{(Figure 9)}

Sweltsa lepnevae Zhiltzova, 1977: 24. (original description of male and female), Zhiltzova 1995: 16. (type catalogue of RAS specimens), Kim et al. 1998: 423. (first Korean records), Ham 2008: 186. (complementary description of male and female), Teslenko \& Zhiltzova 2009: 83. (monograph). 
Type locality. Russia, Primorsky Krai, Chuguevsky Raion, Bereozovy Creek, Pravaya Sokolovka River (Ussuri River Basin).

Material examined. North Korea. North Pyongan Province, Hyangsan-gun, Myohyang Mts, swept at Hyangsan Stream (locality No. 930), 500 $\mathrm{m}, \mathrm{N} 40^{\circ} 00^{\prime} \mathrm{E} 126^{\circ} 15$ ', 21.v.1985, leg. András Vojnits, Lajos Zombori: 1 .

Distribution and ecology. The species was known from the Russian Primorsky Krai and South Korea, but not yet reported from North Korea (Fig. 13). In the Myohyang Mts. it was found together with Perlomyia secunda and Sweltsa colorata.

Remarks. Despite of a single female, the Korean specimen agrees well with the original description. Its head pattern is shown due for comparison with Sweltsa sp. (Fig. 9).

\section{Sweltsa sp.}

(Figure 10)

Material examined. North Korea. Pyongyang capital city, Pyongyang, singled in the garden of Hotel Pyongyang (locality No. 738), $25 \mathrm{~m}, \mathrm{~N} 39^{\circ}$ 00' E12545', 07.vii.1982, leg. László Forró, László Ronkay: 2q; Ryanggang province, Samjiyŏn-gun, Baekdu Mts. Baekdu-san-milyong, singled at a brook in mixed larch-birch forest (locality No. 1353), $1500 \mathrm{~m}, \mathrm{~N} 41^{\circ} 50^{\prime} \mathrm{E} 128^{\circ} 15^{\prime}$, 27.vi.1988, leg. Ottó Merkl, Győző Szél: 3 q.

Diagnosis. Female. Head flat and lacks any dark markings, pronotum with distinct, wide lateral stripes. Median stripe of the abdomen reach anterior margin of tergum IX.

Description. Medium sized species, macropterous. Forewing length: 9-10 mm. Ground colour white in alcohol (probably yellow in life), with dark brown markings on thorax and abdomen. Head wide and flat, completely white and lacks any dark markings (Fig. 10). Ocelli of usual size for the genus, compound eyes small. Antennae and palpi light brown. Pronotum white with distinct, wide dark brown stripes on lateral margins; rugosities indistinct. Meso- and metanotum pale with dark ventrolateral bands, and distinct dorsal U-marks. Legs pale, tarsi brown; wings hyaline, venation yellowish. Pilosity generally short.

Female abdomen. Terga I-VIII with wide dark brown median stripe, markings anteriorly wider on each segments and narrowing on terga VIIVIII; terga IX with transverse dark marking only anteriomedially, tergum X completely white. Sterna all white; subgenital plate large and rounded, posterior margin linear or medially slightly emarginated. Paraproct simple, cerci pale, length usual for the genus.

Distribution and ecology. The species was collected at relatively far and different localities in North Korea; from the highest chains of the Baekdu (Changbai) ranges in the North of the peninsula and from the western lowlands (Fig. 13). In Pyongyang it was collected together with a single Paraleuctra Hanson, 1941 female (probably P. malaisei Zwick, 2010), while in the Baekdu Mts. it was found together with three females of Megarcys ochracea (Klapálek, 1912).

Affinities. Among the known Asian Sweltsa, only this species and the Oriental $S$. yunnan Tierno de Figueroa \& Fochetti, 2002 lacks completely the dark head pattern. Sweltsa sp. probably more close to $S$. lepnevae, as their general body colouration and shape of subgenital plate are mostly similar.

\section{Doubtful records from North Korea}

Several species that were reported from the Chinese border of North Korea (Yalu River, Wu (1938), and Baekdu Mts., Kim et al. (1993)) recently considered to be restricted to Japan. The specimens are not available, so their Korean/ Chinese records are in need of confirmation.

Calineuria jezoensis (Okamoto, 1912). Kim et al. (1993) reported it from the Baekdu Mts., under the name Acroneuria jezoensis Okam. According to Uchida $(1983,1990)$, this species is restricted 


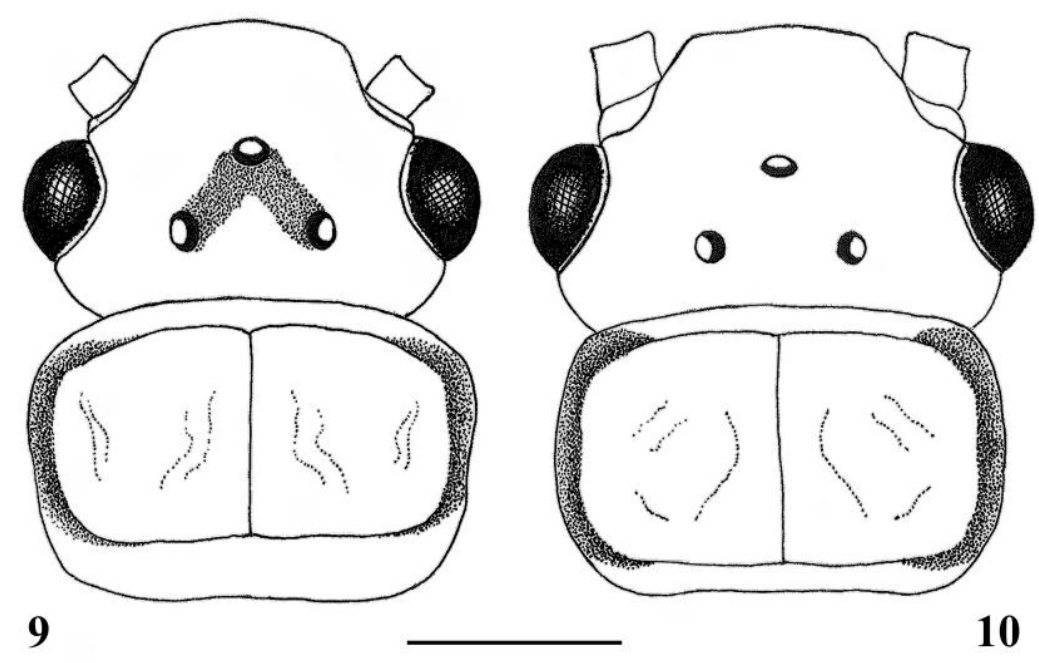

Figures 9-10. Sweltsa Ricker, 1943 species from North Korea, female head and pronotum, dorsal view. $9=$ Sweltsa lepnevae Zhiltzova, 1977 Myohyang Mts; $10=$ Sweltsa sp. Baekdu Mts. Scale $1 \mathrm{~mm}$.

to Japan, just like all the other Asian members of the Transpacific genus Calineuria Ricker, 1954.

Xanthoneuria jouklii (Klapálek, 1907). Kim et al. (1993) reported it from the Baekdu Mts., under the name Acroneuria jouklii Klap. Uchida et al. (2011) reported this species as restricted to Honshu. The record most probably refers to $X$. unimaculata, and its Korean mention in Uchida et al. (2011).

Paragnetina tinctipennis (McLachlan, 1875). Kim et al. (1993) reported it from the Baekdu Mts. According to Uchida (1990), this species is also restricted to Japan. The Korean record probably refers to $P$. flavotincta, widespread in the temperate zone of Asian mainland.

Stavsolus tenninus (Needham, 1905). Wu (1938) reported it from the Yalu River, under the name Togoperla tennina (Needham) (incorrectly indicated as a paratype). Sivec et al. (1988) transferred this species to Stavsolus Ricker, 1952, however, it was not included in the revision of the genus (Teslenko \& Minakawa 1999) and its validity is not yet cleared. The Yalu River specimen probably belongs to Stavsolus manchuricus Terslenko, 1999 (in Teslenko \& Minakawa, 1999), and S. tenninus should be a species restricted to Japan.
Tadamus scriptus (Klapálek, 1912). Kim et al. (1993) reported it from the Baekdu Mts., under the name Isogenus scriptus Klap. The genus $\mathrm{Ta}$ damus Ricker, 1952 is considered to be restricted to Japan, and T. scriptus may belongs to Stavsolus (DeWalt et al. 2015).

Acknowledgements. Thanks are due to Dr. Valentina A. Teslenko (Vladivostok, Russia) for her comments and help. Useful comments of the anonymous reviewers are also appreciated. The research was supported by a grant from the National Institute of Biological Resources (NIBR), funded by the Ministry of Environment (MOE) of the Republic of Korea (NIBR No. 2015-01-203).

\section{REFERENCES}

BANKS, N. (1906): New species of Perlidae. Canadian Entomologist, 38: 335-338. doi:10.4039/Ent38335-10

BANKS, N. (1920): New Neuropteroid Insects. Bulletin of the Museum of Comparative Zoology at Harvard College, 64(3): 299-362 + Pl. I-VII. doi: 10.5962/bhl.title.28705

BANKS, N. (1948): Some characters in the Perlidae. Psyche, 54(4): 266-291. doi: $10.1155 / 1947 / 67653$

DeWalt, R. E., Maehr, M. D., NeU-Becker, U. \& STUEBER, G. (2015): Plecoptera Species File Online. Version $5.0 \mathrm{http}: / /$ Plecoptera.SpeciesFile.org. (accessed 20.07.2015) 

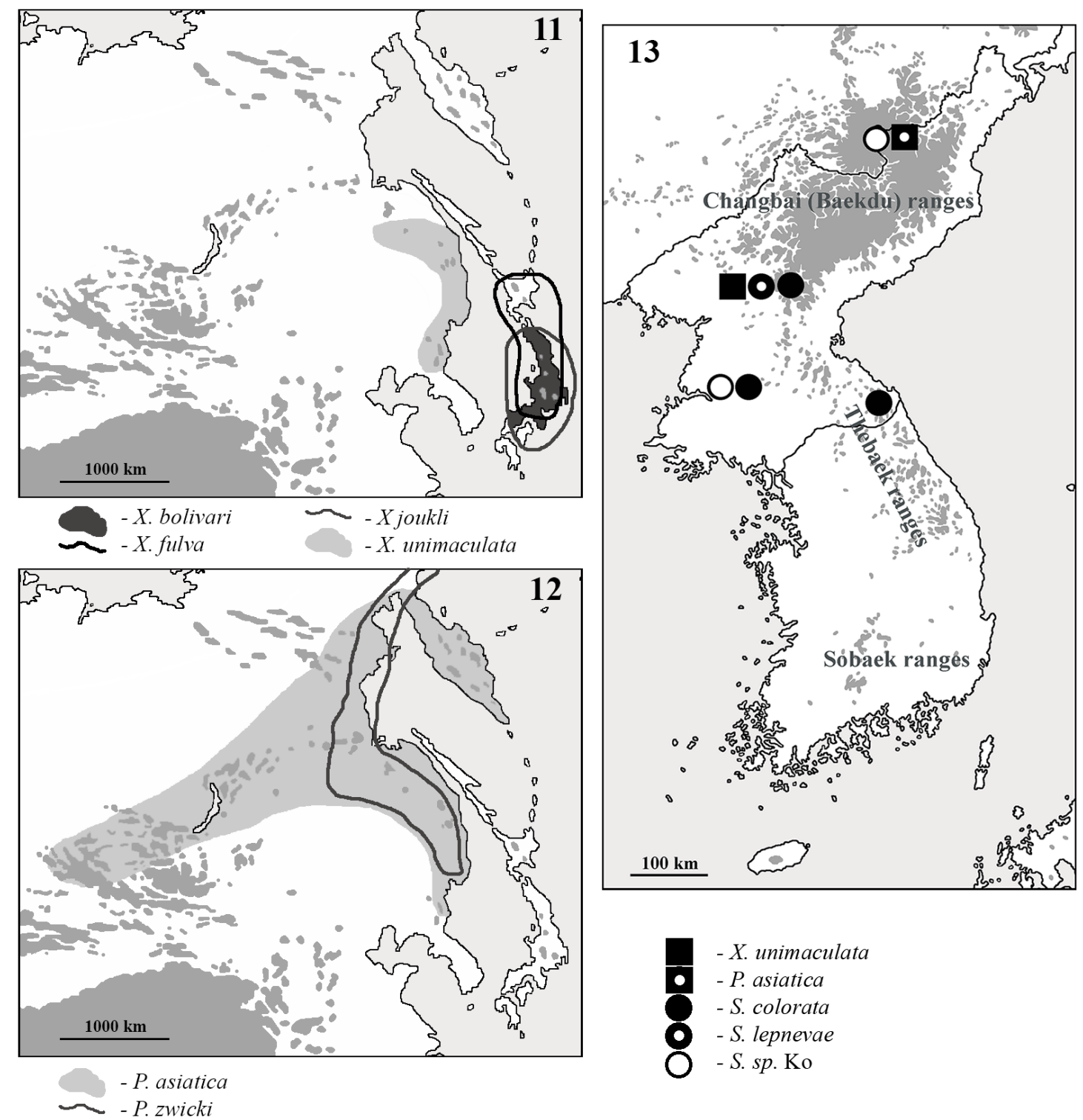

Figures 11-13. Distribution of the genera Xanthoneuria Uchida, 2011 and Pictetiella Illies, 1966, and the North Korean localities reported in the present paper. $11=$ distribution of the genus Xanthoneuria Uchida, 2011; $12=$ Asian distribution of the genus Pictetiella Illies, 1966; 13 = North Korean localities reported in the present paper. Grey areas are above 2000 meters (Figs. 11-12) or 1000 meters (Fig. 13).

FRISON, T. H. (1935): New North American species of the genus Alloperla. Transactions of the American Entomological Society, 61(4): 331-344 + P1. XIXIV.

HAM, S. A. (2008): Two species of Chloroperlidae (Insecta: Plecoptera) new to Korea, with adult keys to species of the family in Korea. Korean Journal of Systematic Zoology, 24: 185-189. doi: $10.5635 / K J S Z .2008 .24 .2 .185$
HANSON, J. F. (1941): Studies on the Plecoptera of North America, II. Bulletin of the Brooklyn entomological Society, Lancester, 36(1): 57-66.

ILLIES, J. (1966): Katalog der rezenten Plecoptera. Das Tierreich, Berlin, 82: 1-632.

Judson, S. W. \& Nelson, C. R. (2012): A guide to Mongolian stoneflies (Insecta: Plecoptera). Zootaxa, 3541: 1-118. doi: 505937B0-9F57-406882E6-8553826DD5AA 
KAWAI, T. (1967): Fauna Japonica. Plecoptera (Insecta). Biogeographical Society of Japan, Tokyo, $211 \mathrm{pp}$.

KIM, J. L., KANG, J. J., LEE, D., KIM, H. S., KANG, S. H., CHOI, S. W., Aw, H. D., KIM, D. S., LEE, M. C., HonG, W. G. \& LeE, G. P. (1993): 8. Plecoptera. A series of Baekdusan: Animal. A compilation committee of a series of Baekdusan. Science Technology Publisher, North Korea, pp. 267-268.

KIM, J. S., BAE, Y. J. \& Zhiltzova, L. A. (1998): Bibliographic review, systematic status, and biogeographic notes on Korean and Far East Russian stoneflies (Insecta: Plecoptera) with their new Korean records. Korean Journal of Biological Sciences, 2: 419-425. doi: $10.1080 / 12265071.1998 .9647440$

KLAPÁLEK, F. (1907): Japonské druhy podčeledi Perlinae. Rozpravy České Akademie císaře Františka Jozefa, 16(31): 1-28.

KLAPÁleK, F. (1912): Plécoptères I. Fam. Perlodidae. Collections Zoologiques du Baron Edm. de Selys Longchamps, 4(1): 1-66.

LAtreille, P. A. (1796): Précis des caractères génériques des insectes, disposés dans un ordre naturel. Brive, Bordeaux, 201 pp.

LeVAnidova, I. M. \& Zhiltzova, L. A. (1976): Vesnyanki (Plecoptera) Chukotskogo poluostrova. Presnovodnaja fauna Chukotskogo poluostrova, Trudy Biologiceskogo-podsvennogo Instituta, Vladivostok, 36(139): 15-37.

LI, W. H., YANG, J. \& YAO, G. (2014): Review of the genus Sweltsa (Plecoptera: Chloroperlidae) in China. Journal of Insect Science, 14(286): 1-8. doi: 10.1093/jisesa/ieu148

MahunKa, S. \& Steinmann, H. (1971): Zoological collectings by the Hungarian Natural History Museum in Korea. 1. A report on the collecting of the first expedition. Folia entomologica hungarica, 24(4): 21-46.

MCLACHLAN, M. R. (1872): Matériaux pour une Faune Névroptérologique de l'Asie Septentrionale. Seconde partie. Non-Odonates. Annales de la Société Entomologique de Belgique, 15: 47-77 + Pl. I-II.

MCLACHLAN, M. R. (1875): A sketch of our present knowledge of the Neuropterous fauna of Japan (excluding Odonata and Trichoptera). The Transactions of the Entomological Society of London, 23(11): 167-190.
MÉSZÁROS, F. \& ZOMBORI, L. (1995): Zoological collectings by the Hungarian Natural History Museum in Korea. 130. A report of the collecting of the twentieth expedition. Folia entomologica hungarica, 56: 109-114.

Murányi, D., Jeon, M. J., Hwang, J. M. \& SeO, H. Y. (2014): Korean species of the genus Perlomyia Banks, 1906 (Plecoptera: Leuctridae). Zootaxa, 3881(2): 145-154. doi: 10.11646/zootaxa.3881.2.3

MurÁnYi, D., Li, W. H., JeON, M. J., HwAng, J. M. \& SEO, H. Y. (2015): Korean species of the genus Neoperla Needham, 1905 (Plecoptera: Perlidae). Zootaxa, 3918(1): 113-127. doi: 10.11646/zootaxa.3918.1.5

MuRÁNYI, D. \& PARK, S. J. (2011): Contribution to the fall stonefly (Plecoptera) fauna of Korea. Illiesia, 7(6): 70-85.

NeEDHAM, J. G. (1905): New genera and species of Perlidae. Proceedings of the Biological Society of Washington, 18: 107-110.

Nelson, C. H. \& Hanson, J. F. (1973): The genus Perlomyia (Plecoptera: Leuctridae). Journal of the Kansas Entomological Society, 46: 187-199.

OKамото, H. (1912): Erster Beiträg zur Kenntnis der Japanischer Plecopteren. Transactions of the Sapporo Natural History Society, 4: 105-170.

Ra, C. H., Kim, J. S., Kang, Y. W. \& Ham, S. A. (1994): Taxonomic study on three families (Peltoperlidae, Perlodidae, Perlidae) of stoneflies (Plecoptera) in Korea. The Korean Journal of Systematic Zoology, 10(1): 1-15.

RICKER, W. E. (1943): Stoneflies of Southwestern British Columbia. Indiana University Publications, Science Series, 12: 1-145.

RICKER, W. E. (1952): Systematic studies in Plecoptera. Indiana University Publications, Science Series, 18: 1-200.

RICKER, W. E. (1954): Nomenclatorial notes on Plecoptera. Proceedings of the Entomological Society of British Columbia, 51: 37-39.

RIS, F. (1902): Die schweizerischen Arten der Perlidengattung Nemura. Mitteilungen der Schweizerischen entomologischen Gesellschaft, 10: 378405 .

Sivec, I., Stark, B. P. \& UchIDA, S. (1988): Synopsis of the World genera of Perlinae (Plecoptera: Perlidae). Scopolia, 16: 1-66. 
StARK, B. P. (2010): Studies on Korean stoneflies (Insecta: Plecoptera) with descriptions of two new species. Illiesia, 6(1): 1-10.

StARK, B. P. \& KondratiefF, B. C. (2004): Pictetiella lechleitneri (Plecoptera: Perlodidae), a new species from Mount Rainier National Park, Washington, U.S.A. Proceedings of the Entomological Society of Washington, 106(4): 747-750.

StARK, B. P. \& SiVEC, I. (2008a): New stoneflies (Plecoptera) from Asia. Illiesia, 4(1): 1-10.

STARK, B. P. \& SIVEC, I. (2008b): Systematic notes on Kiotina Klapálek and Hemacroneuria Enderlein (Plecoptera: Perlidae), with description of four new species. Illiesia, 4(17): 161-175.

StARK, B. P. \& SiveC, I. (2009): Sweltsa wui and Haploperla valentinae (Plecoptera: Chloroperlidae), two new stoneflies from Sichuan province, China. Illiesia, 5(14): 156-163.

SteWART, K. W. \& StARK, B. P. (2002): Nymphs of North American stonefly genera (Plecoptera). $2^{\text {nd }}$ Edition. The Caddis Press, Columbus, Ohio, 510 pp.

SURDICK, R. F. (1985): Nearctic genera of Chloroperlinae (Plecoptera: Chlroroperlidae). Illinois Biological Monographs, 54: 1-146.

TesLenko, V. A. (2012): Fauna vesnyanok (Insecta, Plecoptera) Evrejskoj avtonomnoj oblasti. Eurasian Entomological Journal, 11(1): 29-36.

Teslenko, V. A. \& MinaKawa, N. (1999): Two new species of the genus Stavsolus Ricker from the Asian Far East (Plecoptera: Perlodidae). Aquatic Insects, 21(1): 19-32.

Teslenko, V. A. \& Zhiltzova, L. A. (2009): Key to the stoneflies (Insecta, Plecoptera) of Russia and adjacent countries. Imagines and nymphs. Russian Academy of Sciences Dalnauka, Vladivostok, 382 pp.

Tierno De FigueroA, J. M. \& Fochetti, R. (2002): Sweltsa yunnan, sp. nov.; a new stonefly from China (Plecoptera: Chloroperlidae). Oriental Insects, 36: 93-95. doi: $\underline{10.1080 / 00305316.2002 .10417327}$

UCHIDA, S. (1983): A new species of Calineuria (Plecoptera, Perlidae) from Japan, with notes on the Japanese species of the genus. Kontyú, Tokyo, 51(4): 622-627.
UCHIDA, S. (1990): A revision of the Japanese Perlidae (Insecta: Plecoptera), with several reference to their phylogeny. PhD Thesis, Tokyo Metropolitan University, Tokyo, $228 \mathrm{pp}$.

Uchida, S., Stark, B. P. \& Sivec, I. (2011): Xanthoneuria, a new genus of stonefly (Plecoptera: Perlidae) from Japan. Illiesia, 7(5): 65-69.

WU, C. F. (1938): Plecopterorum sinensium: A monograph of stoneflies of China (Order Plecoptera). Yenching University, Beijing, 225 pp. + Pl. IXLVII.

ZAPEKINA-DULKEIT, J. I. (1955): Vesnyanki severovostochnogo Altaya. Zametki po Faune i Flore Sibiri, 18: 30-38.

ZhiltzovA, L. A. (1974): Redkie rody vesnyanok sem. Leuctridae (Insecta, Plecoptera) $\mathrm{v}$ faune SSSR. Zoologicheskiy Zhurnal, 53(3): 359-364.

Zhiltzova, L. A. (1975): Rhopalopsole - novy dlya fauny SSSR rod vesnyanok (Plecoptera, Leuctridae). Zoologicheskiy Zhurnal, 54(2): 221-230.

ZhiltzovA, L. A. (1977): Materialy po faune vesnyanok (Insecta, Plecoptera) verkhney chasti basseyna Reki Ussuri v Primorskom Kraye. Entomofauna Dalnego Vostoka, Trudy Biologo-pochvennogo Instituta, Vladivostok, 46(149): 17-27.

ZhiltzovA, L. A. (1981): Novye vidy vesnyanok (Plecoptera) s Dalnego Vostoka. Morfologiya i systematika nasekomikh Dalnego Vostoka, Trudy Zoologicheskogo Instituta Akademia Nauk SSSR, 81: 3-6.

ZhiltzovA, L. A. (1995): Katalog tipovykh ekzemplyarov kollektsii Zoologicheskogo Instituta RAN. Vesnyanki (Plecoptera). SPB, St. Petersburg, 37 pp.

Zhiltzova, L. A. \& LeVANIDOVA, I. M. (1978): Novye vidy vesnyanok (Plecoptera) s Dalnego Vostoka. Novye vidy zhivotnykh, Trudy Zoologiceskogo Instituta Akademia Nauk SSSR, 61: 3-29.

ZhiltzovA, L. A. \& ZAPEKINA-DULKeIT, J. I. (1986): 10. Otrjad Plecoptera - Vesnyanki. Opredelitej nasekomih Dalnego Vostoka SSSR, Leningrad, 1: 172-234.

ZWICK, P. (1973a): On the stoneflies from Korea (Insecta, Plecoptera). Fragmenta Faunistica, 19(8): 149-157. doi: 10.3161/00159301FF1973.19.8.149

ZWICK, P. (1973b): Plecoptera from Korea. Annales Historico-naturales Musei Nationalis Hungarici, 65: $157-169$. 
ZWICK, P. (1983): The Neoperla of Sumatra and Java (Indonesia) (Plecoptera: Perlidae). Spixiana, 6(2): 167-204.

ZWICK, P. (2010): New species and new records of Plecoptera from Korea and the Russian Far East. Illiesia, 6(9): 75-97.

ZWICK, P. \& BAUMANN, R. W (2011): Nemoura jejudoensis a new species of stonefly and the redescription of Amphinemura baei Ham and Lee
(Plecoptera, Nemouridae) from Jeju Island, Korea. Illiesia, 7(15): 148-155.

Zwick, P., Levanidova, I. M. \& Zhiltzova, L. A. (1971): On the fauna of Plecoptera from the Soviet Far East. (in Russian) Revue d'Entomologie de l'URRS, 50(4): 849-869.

ZWICK, P. \& WEINZIERL, A. (1995): Reinstatement and revision of genus Besdolus (Plecoptera: Perlodidae). Entomologica Scandinavica, 26: 1-16. 